\title{
Effects of acute changes in systemic arterial pressure on left ventricular diastolic stiffness and mass ${ }^{1}$
}

\author{
BRUCE R. BRODIE AND LAMBERT P. MCLAURIN \\ From the Department of Medicine, University of North Carolina School of Medicine; and the C. V. Richardson \\ Cardiac Catheterization Laboratory, Chapel Hill, NC 27514, USA
}

SUMMARY Acute interventions may shift the left ventricular diastolic pressure-volume curve in man, but the mechanism is unclear. Methoxamine hydrochloride was given to 7 patients without coronary disease to raise mean arterial pressure 25 to $35 \mathrm{mmHg}$. High fidelity left ventricular pressures were recorded simultaneously with single plane cine left ventriculography and pressure-volume curves were constructed before and during methoxamine infusion. Methoxamine significantly increased left ventricular end-diastolic pressure $(12 \pm 1$ vs $25 \pm 1 \mathrm{mmHg})$, left ventricular minimal diastolic pressure $(6 \pm 1$ vs $15 \pm 2 \mathrm{mmHg})$, right atrial pressure $(5 \pm 1 \mathrm{vs} 9 \pm 1 \mathrm{mmHg})$, left ventricular end-diastolic volume $(185 \pm 32$ vs $207 \pm 37 \mathrm{ml})$, left ventricular end-systolic volume $(72 \pm 19$ vs $93 \pm 25 \mathrm{ml})$, and left ventricular mass $(168 \pm 17$ vs $187 \pm 18 \mathrm{~g})$, while left ventricular wall thickness changed little $(8 \cdot 5 \pm 0 \cdot 6$ vs $8.7 \pm 0.5 \mathrm{~mm}$ ). In each patient the diastolic pressure-volume curve was shifted upward, with left ventricular pressure being higher for any given volume with methoxamine. Serial ventriculograms in 5 subjects who did not receive methoxamine showed no shift. Since methoxamine has no effect on the myocardium and since the subjects had no evidence of left ventricular ischaemia, it is unlikely that the changes in the pressure-volume curve are caused by intrinsic changes in myocardial properties. Viscous properties cannot solely account for the observations, since the diastolic filling rate was altered only in the first one-third of diastole. The increase in left ventricular wall mass suggests that acute increases in systemic arterial pressure may augment left ventricular stiffness by coronary vascular engorgement and an erectile effect on the myocardium. The study cannot exclude pericardial restriction and changes in right ventricular loading as contributing factors in acute shifts in the left ventricular diastolic pressure-volume curve.

Recently, it has been recognised that acute interventions may alter the relation between left ventricular diastolic pressure and volume in man. Patients with coronary artery disease who develop angina may shift the pressure-volume curve upward so that, at a given volume, pressures are higher during angina (Barry et al., 1974; Flessas et al., 1976; Mann et al., 1977); and patients with congestive heart failure or coronary artery disease may shift the pressure-volume curve downward with nitroprusside or glyceryl trinitrate so that, at a given volume, pressures are lower during vasodilator therapy (Alderman and Glantz, 1976; Parmley et al., 1976;

\footnotetext{
1Supported by a North Carolina Heart Association grant, a University of North Carolina Research Council grant, and a University of North Carolina Medical School Faculty grant.
}

Received for publication 5 June 1978
Brodie et al., 1977). It is not clear whether these shifts are the result of intrinsic changes in myocardial properties or the result of changes in one or more of the extrinsic constraints to left ventricular filling, such as right ventricular loading, pericardial restriction, or coronary artery perfusion pressure. The present study was designed to help clarify the potential role of these extramyocardial factors in acute changes in the diastolic pressure-volume relation. Pharmacological intervention with methoxamine hydrochloride was chosen because this drug acts selectively to increase systemic vascular resistance and systemic arterial pressure with little or no effect on the myocardium (Eckstein and Abboud, 1962). The results indicate that acute rises in systemic arterial pressure increase left ventricular wall mass and diastolic stiffness and suggest that this may be the result of coronary vascular engorgement and an erectile effect on the myocardium. 
Table Haemodynamic and angiographic data before and during methoxamine infusion

\begin{tabular}{|c|c|c|c|c|c|c|c|c|c|c|}
\hline $\begin{array}{l}\text { Case } \\
\text { no. }\end{array}$ & Diagnosis & $\begin{array}{l}C I \\
\left(l / \min \text { per } m^{2}\right)\end{array}$ & $\begin{array}{l}H R \\
(b / \min )\end{array}$ & $\begin{array}{l}\text { SVR } \\
\text { (dynes s } \\
\left.c^{-5}\right)\end{array}$ & $\underset{(m m H g)}{S A}$ & $\begin{array}{l}R A \\
(m m H g)\end{array}$ & $\underset{(m m H g)}{L V E D P}$ & $\begin{array}{l}\text { LVMDP } \\
(\mathrm{mmHg})\end{array}$ & $\begin{array}{l}+d P / d t \\
(m m H g / s)\end{array}$ & $\begin{array}{l}-d P / d \overline{\bar{s}} \\
\text { (mmHg/f) }\end{array}$ \\
\hline 1 & CPNC & $\begin{array}{ll}\text { C } & 3.7 \\
\text { M } & 3.6\end{array}$ & $\begin{array}{l}85 \\
83\end{array}$ & $\begin{array}{l}1482 \\
1853\end{array}$ & $\begin{array}{l}115 \\
145\end{array}$ & $\begin{array}{l}2 \\
6\end{array}$ & $\begin{array}{l}14 \\
22\end{array}$ & $\begin{array}{r}4 \\
12\end{array}$ & $\begin{array}{l}1400 \\
1633\end{array}$ & 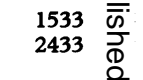 \\
\hline 2 & $\mathrm{CM}$ & $\begin{array}{ll}\text { C } & 3.6 \\
\text { M } & 3.9\end{array}$ & $\begin{array}{l}65 \\
77\end{array}$ & $\begin{array}{l}1045 \\
1185\end{array}$ & $\begin{array}{l}105 \\
130\end{array}$ & $\begin{array}{r}7 \\
10\end{array}$ & $\begin{array}{l}15 \\
26\end{array}$ & $\begin{array}{r}9 \\
17\end{array}$ & $\begin{array}{r}800 \\
1200\end{array}$ & 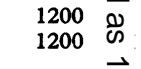 \\
\hline 3 & CPNC & $\begin{array}{ll}\text { C } & 2 \cdot 8 \\
\text { M } 3 \cdot 1\end{array}$ & $\begin{array}{l}84 \\
78\end{array}$ & $\begin{array}{l}1745 \\
2054\end{array}$ & $\begin{array}{l}100 \\
127\end{array}$ & $\begin{array}{l}4 \\
6\end{array}$ & $\begin{array}{l}13 \\
26\end{array}$ & $\begin{array}{l}5 \\
8\end{array}$ & - & - \\
\hline 4 & CPNC & $\begin{array}{ll}\text { C } & 2 \cdot 3 \\
M & 2 \cdot 6\end{array}$ & $\begin{array}{r}98 \\
103\end{array}$ & $\begin{array}{r}836 \\
2007\end{array}$ & $\begin{array}{r}93 \\
135\end{array}$ & $\begin{array}{l}1 \\
7\end{array}$ & $\begin{array}{r}8 \\
30\end{array}$ & $\begin{array}{r}3 \\
21\end{array}$ & $\begin{array}{l}1020 \\
1620\end{array}$ & 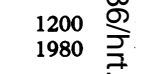 \\
\hline 5 & CPNC & $\begin{array}{ll}\text { C } & 4 \cdot 2 \\
M & 4.5\end{array}$ & $\begin{array}{l}85 \\
81\end{array}$ & $\begin{array}{r}834 \\
1127\end{array}$ & $\begin{array}{l}105 \\
150\end{array}$ & $\begin{array}{r}6 \\
10\end{array}$ & $\begin{array}{l}11 \\
26\end{array}$ & $\begin{array}{r}6 \\
13\end{array}$ & $\begin{array}{l}2520 \\
3150\end{array}$ & 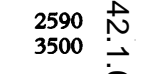 \\
\hline 6 & CPNC & $\begin{array}{ll}\text { C } & 3.4 \\
\text { M } & 3.5\end{array}$ & $\begin{array}{l}78 \\
78 \\
\end{array}$ & $\begin{array}{l}1059 \\
1424\end{array}$ & $\begin{array}{l}100 \\
140\end{array}$ & $\begin{array}{r}6 \\
10\end{array}$ & $\begin{array}{l}11 \\
25\end{array}$ & $\begin{array}{r}7 \\
11\end{array}$ & $\begin{array}{l}1143 \\
1314\end{array}$ & $\begin{array}{l}1714 \text { ㅇ } \\
2057 \text { 음 }\end{array}$ \\
\hline 7 & $\begin{array}{l}\text { CPNC, } \\
\text { SSS }\end{array}$ & $\begin{array}{ll}C & 1.4 \\
M & 1.4\end{array}$ & $\begin{array}{l}77 \\
77\end{array}$ & $\begin{array}{l}3319 \\
3685\end{array}$ & $\begin{array}{l}118 \\
140\end{array}$ & $\begin{array}{r}6 \\
11\end{array}$ & $\begin{array}{l}14 \\
25\end{array}$ & $\begin{array}{r}8 \\
22\end{array}$ & - & $\overline{-}$ \\
\hline \multicolumn{2}{|c|}{ Mean \pm SEM } & $\begin{array}{ll}C & 3.1 \pm 0.4 \\
M & 3.2 \pm 0.4\end{array}$ & $\begin{array}{l}82 \pm 4 \\
82 \pm 4\end{array}$ & $\begin{array}{l}1474 \pm 333 \\
1905 \pm 329\end{array}$ & $\begin{array}{l}105 \pm 9 \\
138 \pm 3\end{array}$ & $\begin{array}{l}5 \pm 1 \\
9 \pm 1\end{array}$ & $\begin{array}{l}12 \pm 1 \\
25 \pm 1\end{array}$ & $\begin{array}{r}6 \pm 1 \\
15 \pm 2\end{array}$ & $\begin{array}{l}1376 \pm 302 \\
1783 \pm 352\end{array}$ & $\begin{array}{l}1647 \pm 251 \\
2234 \pm \sqrt[39 !]{ }\end{array}$ \\
\hline \multicolumn{2}{|c|}{$\begin{array}{l}t \text { value } \\
\mathbf{P}\end{array}$} & $\begin{array}{r}2.66 \\
<0.05 \\
\end{array}$ & $\begin{array}{r}0.31 \\
\text { NS } \\
\end{array}$ & $\begin{array}{r}3.39 \\
<0.02 \\
\end{array}$ & $\begin{array}{c}9.53 \\
<0.001 \\
\end{array}$ & $\begin{array}{c}8.20 \\
<0.001 \\
\end{array}$ & $\begin{array}{r}8.02 \\
<0.001 \\
\end{array}$ & $\begin{array}{r}4.37 \\
<0.005 \\
\end{array}$ & $\begin{array}{c}4.37 \\
<0.005\end{array}$ & $\begin{array}{r}3.27 \quad 0 \\
<0.02 \quad 0 \\
\end{array}$ \\
\hline
\end{tabular}

CPNC, chest pain with normal coronary angiography; CM, cardiomyopathy; SSS, sick sinus syndrome; CI, cardiac index; HR, heart rate systemic vascular resistance; SA, mean arterial pressure; RA, mean right atrial pressure; LVEDP, left ventricular end-diastolic pressure; $L$ VA left ventricular minimal diastolic pressure; $+\mathrm{dP} / \mathrm{dt}$, peak positive $\mathrm{dP} / \mathrm{dt} ;-\mathrm{dP} / \mathrm{dt}$, peak negative $\mathrm{dP} / \mathrm{dt} ; \mathrm{EDV}$, left ventricular end-diastolic valu ESV, left ventricular end-systolic volume; $S V$, angiographic stroke volume; EF, ejection fraction; Mass, left ventricular mass; DFR diastolich rate in first $1 / 3$ of diastole; $D_{F}$, diastolic filling rate in middle $1 / 3$ of diastole; $D F R_{3}$, diastolic filling rate in last $1 / 3$ of diastole; $D F R_{T}$, diastolief rate for diastole as a whole; $C$, control; $M$, methoxamine.

\section{Methods}

PATIENTS

Patients with chest pain but without objective clinical evidence of ischaemic heart disease who were scheduled for routine diagnostic cardiac catheterisation at North Carolina Memorial Hospital were invited to participate in the study. The experimental procedure was approved by the Hospital Committee on the Rights of Human Subjects, and informed consent was obtained from each patient. Patients with significant coronary artery obstructions by angiography, mitral valve prolapse, or hypertrophic cardiomyopathy were excluded from the study. The study group thus consisted of 7 patients (Table). Five patients had chest pain syndromes with normal coronary and left ventricular angiography and normal or nearly normal haemodynamics. One patient (case 2) had haemodynamic and angiographic evidence of a mild congestive cardiomyopathy probably secondary to alcohol, and 1 patient (case 7) had sick sinus syndrome, with a permanent transvenous ventricular demand pacemaker and a low cardiac index. Four patients (cases $1,5,6$, and 7) had a history of mild hypertension and 3 patients (cases 2, 4, 6) were taking propranolol 80 to $160 \mathrm{mg} /$ day which was discontinued 12 to 36 hours before the procedure.

\section{METHODS AND EQUIPMENT}

Cardiac catheterisation was performed in the fasting state using the right brachial arterial approach after premedication with diazepam (Valium, $10 \mathrm{mg} \mathrm{po}$ ) and atropine sulphate $(0.5 \mathrm{mg}$ intravenously). Right heart catheterisation was performed using a Gorlin pacing catheter. Left ventricular pressure was recorded using high fidelity micromanometer tipped catheters (Mikrotip, Millar Instruments, Houston, Texas) in all patients to permit accurate measurement of ventricular pressure simultaneously with the performance of cineangiography. The patients were instructed to avoid deep respirations and the Valsalva manoeuvre during the cineangiogram and recording of pressures. The first derivative of left ventricular pressure $(\mathrm{dP} / \mathrm{dt})$ was obtained using a passive (resistance-capacitance) differentiating circuit with a $0.5 \mathrm{~ms}$ time constant and an output linearly proportional to the input frequency, within 5 per cent, up to a rated maximal frequency of $75 \mathrm{~Hz}$. Single plane (RAO) left ventricular cineangiography was performed with the injection of 30 to $40 \mathrm{ml}$ of radiographic contrast material (Renografin 76, E. R. 


\begin{tabular}{|c|c|c|c|c|c|c|c|c|c|}
\hline $\begin{array}{l}P V \\
l)\end{array}$ & $\begin{array}{l}E S V \\
(m l)\end{array}$ & $\begin{array}{l}S V \\
(m l)\end{array}$ & $E F$ & $\begin{array}{l}L V \text { wall } \\
\text { thickness } \\
(\mathrm{mm})\end{array}$ & $\begin{array}{l}\text { Mass } \\
(\mathrm{g})\end{array}$ & $\begin{array}{l}D F R_{1} \\
(m l / s)\end{array}$ & $\begin{array}{l}D F R_{2} \\
(\mathrm{ml} / \mathrm{s})\end{array}$ & $\begin{array}{l}D F R_{\mathbf{z}} \\
(\mathrm{ml} / \mathrm{s})\end{array}$ & $\begin{array}{c}D F R_{T} \\
(m l / s)\end{array}$ \\
\hline $\begin{array}{l}3 \\
5\end{array}$ & $\begin{array}{l}31 \\
38\end{array}$ & $\begin{array}{l}78 \\
68\end{array}$ & $\begin{array}{l}0.72 \\
0.64\end{array}$ & $\begin{array}{l}8 \cdot 5 \\
9 \cdot 0\end{array}$ & $\begin{array}{l}134 \\
141\end{array}$ & $\begin{array}{l}278 \\
277\end{array}$ & $\begin{array}{l}159 \\
388\end{array}$ & $\begin{array}{l}222 \\
268\end{array}$ & $\begin{array}{l}200 \\
290\end{array}$ \\
\hline 1 & $\begin{array}{l}180 \\
233\end{array}$ & $\begin{array}{l}184 \\
168\end{array}$ & $\begin{array}{l}0.51 \\
0.42\end{array}$ & $\begin{array}{l}7.5 \\
7.5\end{array}$ & $\begin{array}{l}217 \\
237\end{array}$ & $\begin{array}{l}786 \\
815\end{array}$ & $\begin{array}{l}201 \\
343\end{array}$ & $\begin{array}{l}444 \\
478\end{array}$ & $\begin{array}{l}465 \\
549\end{array}$ \\
\hline 3 & $\begin{array}{l}40 \\
59\end{array}$ & $\begin{array}{l}113 \\
111\end{array}$ & $\begin{array}{l}0.74 \\
0.65\end{array}$ & $\begin{array}{l}6 \cdot 5 \\
7 \cdot 0\end{array}$ & $\begin{array}{l}111 \\
134\end{array}$ & $\begin{array}{l}254 \\
407\end{array}$ & $\begin{array}{l}269 \\
148\end{array}$ & $\begin{array}{l}396 \\
435\end{array}$ & $\begin{array}{l}314 \\
343\end{array}$ \\
\hline ; & $\begin{array}{r}75 \\
100\end{array}$ & $\begin{array}{l}101 \\
126\end{array}$ & $\begin{array}{l}0.57 \\
0.56\end{array}$ & $\begin{array}{l}8.5 \\
8.5\end{array}$ & $\begin{array}{l}166 \\
193\end{array}$ & $\begin{array}{r}416 \\
1000\end{array}$ & $\begin{array}{l}426 \\
167\end{array}$ & $\begin{array}{l}511 \\
291\end{array}$ & $\begin{array}{l}467 \\
500\end{array}$ \\
\hline 3 & $\begin{array}{l}58 \\
63\end{array}$ & $\begin{array}{l}100 \\
106\end{array}$ & $\begin{array}{l}0.63 \\
0.63\end{array}$ & $\begin{array}{l}11.5 \\
11.5\end{array}$ & $\begin{array}{l}233 \\
236\end{array}$ & $\begin{array}{l}481 \\
958\end{array}$ & $\begin{array}{l}241 \\
361\end{array}$ & $\begin{array}{l}244 \\
153\end{array}$ & $\begin{array}{l}327 \\
491\end{array}$ \\
\hline ! & $\begin{array}{l}75 \\
87\end{array}$ & $\begin{array}{l}129 \\
154\end{array}$ & $\begin{array}{l}0.63 \\
0.64\end{array}$ & $\begin{array}{l}8.5 \\
9 \cdot 0\end{array}$ & $\begin{array}{l}184 \\
223\end{array}$ & $\begin{array}{l}491 \\
806\end{array}$ & $\begin{array}{l}296 \\
644\end{array}$ & $\begin{array}{r}407 \\
83\end{array}$ & $\begin{array}{l}398 \\
503\end{array}$ \\
\hline i & $\begin{array}{l}48 \\
71\end{array}$ & $\begin{array}{l}81 \\
65\end{array}$ & $\begin{array}{l}0.63 \\
0.48\end{array}$ & $\begin{array}{l}8 \cdot 5 \\
8 \cdot 5\end{array}$ & $\begin{array}{l}132 \\
142\end{array}$ & $\begin{array}{l}500 \\
472\end{array}$ & $\begin{array}{l}95 \\
78\end{array}$ & $\begin{array}{l}56 \\
78\end{array}$ & $\begin{array}{l}225 \\
226\end{array}$ \\
\hline $\begin{array}{l} \pm 32 \\
\pm 37\end{array}$ & $\begin{array}{l}72 \pm 19 \\
93 \pm 25\end{array}$ & $\begin{array}{l}112 \pm 13 \\
114 \pm 15\end{array}$ & $\begin{array}{l}0.63 \pm 0.03 \\
0.57 \pm 0.03\end{array}$ & $\begin{array}{l}8.5 \pm 0.6 \\
8.7 \pm 0.5\end{array}$ & $\begin{array}{l}168 \pm 17 \\
187 \pm 18\end{array}$ & $\begin{array}{l}458 \pm 67 \\
676 \pm 108\end{array}$ & $\begin{array}{l}241 \pm 40 \\
304 \pm 73\end{array}$ & $\begin{array}{l}326 \pm 60 \\
255 \pm 60\end{array}$ & $\begin{array}{l}342 \pm 40 \\
415 \pm 48\end{array}$ \\
\hline $\begin{array}{l}i .06 \\
1.025\end{array}$ & $\begin{array}{r}3.35 \\
<0.02\end{array}$ & $\begin{array}{l}0 \cdot 26 \\
\text { NS }\end{array}$ & $\begin{array}{r}2.60 \\
<0.05\end{array}$ & $\begin{array}{l}2 \cdot 12 \\
\text { NS }\end{array}$ & $\begin{array}{r}3.86 \\
<0.01\end{array}$ & $\begin{array}{l}2 \cdot 36 \\
\text { NS }\end{array}$ & $\begin{array}{l}0.80 \\
\text { NS }\end{array}$ & $\begin{array}{l}1 \cdot 26 \\
\text { NS }\end{array}$ & $\begin{array}{l}3.45 \\
<0.02\end{array}$ \\
\hline
\end{tabular}

Squibb \& Sons, Inc., Princeton, NJ) into the ventricular chamber at a rate of 10 to $15 \mathrm{ml}$ per second. A Siemens caesium iodide image intensifier was used and cineangiograms were recorded on $35 \mathrm{~mm}$ film at 56 frames per second. Care was taken to ensure that neither the patient nor the equipment was moved and that the degree of obliquity was reproduced between sequential RAO angiograms. A movable marker synchronised with the QRS complex of the electrocardiogram was filmed with the cineangiogram and used to identify end-diastole. A recording of the electrocardiogram, high fidelity left ventricular pressure, injection marker, and cineangiographic frame markers was made simultaneously with the cineangiogram, and enabled left ventricular pressures to be matched with left ventricular angiographic silhouettes throughout the cardiac cycle (Fig. 1).

\section{EXPERIMENTAL PROCEDURE}

After placement of the catheters, baseline (control) measurements were made of Fick or indicator dilution cardiac output, systemic arterial pressure (SA), right atrial pressure (RA), high fidelity left ventricular pressure, and the first derivative of left ventricular pressure with respect to time $(\mathrm{dP} / \mathrm{dt})$. Control left ventricular cineangiography and simultaneous high fidelity left ventricular pressure measurement were then performed. Ten to 15 minutes later, after intracardiac pressures had returned to baseline, methoxamine hydrochloride (Vasoxyl, $100 \mathrm{mg}$ in $\left.500 \mathrm{ml} \mathrm{D}_{5} \mathrm{~W}\right)$ was infused to raise mean arterial pressure 25 to $35 \mathrm{mmHg}$, and this state was maintained for 10 minutes. In order to prevent the reflex bradycardia that occurs with methoxamine infusion, the heart was paced at a heart rate approximately equal to the control heart rate with the pacing catheter positioned in the high right atrium. Cardiac output, intracardiac pressure measurements, and left ventricular cineangiography were repeated and methoxamine was then discontinued. In 5 control subjects with chest pain and normal coronary angiography, 2 left ventricular cineangiograms with high fidelity left ventricular pressure measurements were performed 10 to 15 minutes apart, without methoxamine infusion, to assess the effect of the cineangiogram itself on the diastolic pressurevolume relation. The high fidelity left ventricular pressure was balanced with the pressure measured through the fluid-filled lumen of the Millar catheter before and after each cineangiogram to ensure that there was no drift in the high fidelity pressure. 


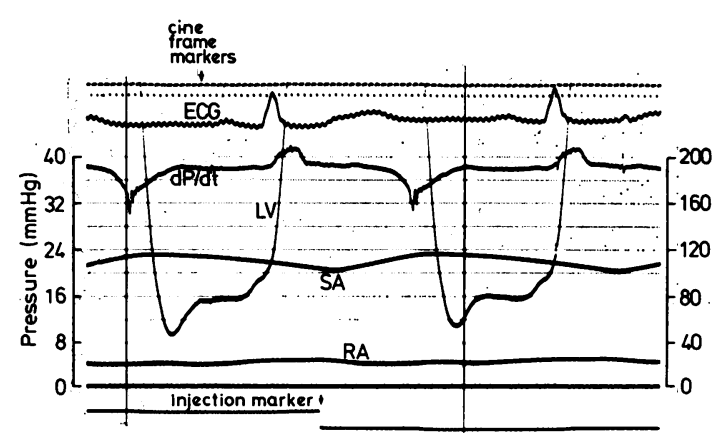

Fig. 1 Recording of the electrocardiogram (ECG), high fidelity left ventricular pressure ( $L V)$, first derivative of left ventricular pressure with respect to time $(d P / d t)$, mean systemic arterial pressure $(S A)$, mean right atrial pressure $(R A)$, injection marker, and cineangiographic frame markers made simultaneously with the left ventricular cineangiogram. The injection marker signals the time at which contrast material is injected into the left ventricular chamber and enables cardiac cycles on the pressure tracing to be matched with corresponding cycles on the cineangiogram. The electrocardiogram and cineangiographic frame markers, combined with a moveable marker synchronised with the QRS complex of the electrocardiogram and recorded on the cineangiogram, enable left ventricular pressures to be matched with left ventricular angiographic silhouettes throughout each cardiac cycle.

ANALYSIS OF DATA

For each patient, left ventricular angiographic silhouettes were traced every frame ( $18 \mathrm{~ms}$ intervals) from initial diastole, which was defined as the angiographic frame immediately before the mitral valve opening movement, to end-diastole, which was defined as the angiographic frame during which the QRS marker first moved. The earliest adequately visualised beats were used, and the first 2 beats after premature systoles were excluded. High fidelity left ventricular pressures, recorded simultaneously with the cineangiogram, were matched with left ventricular angiographic silhouettes as shown in Fig. 1. Left ventricular volumes were calculated using the area-length method and a grid calibration technique (Kasser and Kennedy, 1969) with the help of a sonic digitiser (Science Assessories Corp., Southport, Conn.) interfaced to a programmable calculator (Wang Laboratories, Inc., Tewksbury, Mass). Interobserver variation in the measurement of volumes by this technique was found to be less than 4 per cent. Pressure-volume curves were constructed throughout diastole for each study patient from data obtained during the control period and during methoxamine infusion. Pressure-volume curves were also constructed for the 5 subjects who had serial angiograms without methoxamine infusion.

Left ventricular wall thickness was measured at end-diastole in the RAO projection (Rackley et al., 1964; Kennedy et al., 1970), and correction for magnification was made using a grid calibration technique. Left ventricular mass was calculated at end-diastole using ellipsoidal formulas assuming uniform left ventricular wall thickness.

Diastolic filling rates were measured as the change in calculated ventricular volume during diastole divided by the time over which this change occurred as determined from the number of cineangiographic frames elapsed. Diastolic filling rates were measured during the first, middle, and last thirds of diastole and for total diastole during both the control state and during methoxamine infusion.

Comparisons of haemodynamic and angiographic indices between the control period and methoxamine infusion were made using a two-tailed paired t test.

\section{Results}

The relation between left ventricular diastolic pressure and volume in the control state and during methoxamine infusion for each of the 7 study patients is shown in Fig. 2 and 3. In each subject there was a substantial upward displacement of the

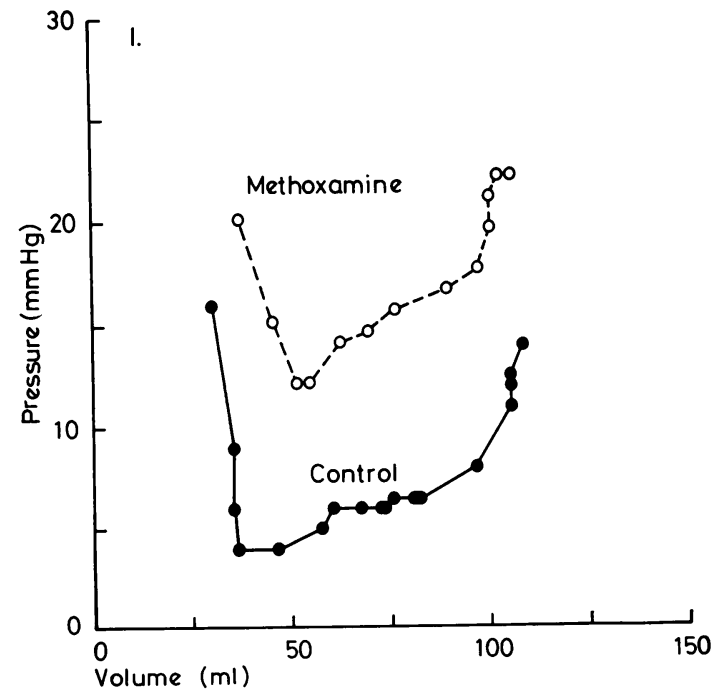

Fig. 2 Left ventricular diastolic pressure-volume curves before and during methoxamine infusion in a patient with chest pain and normal coronary angiography (case 1, Table). The curve is shifted upward with left ventricular pressure being higher for any given volume with methoxamine. 


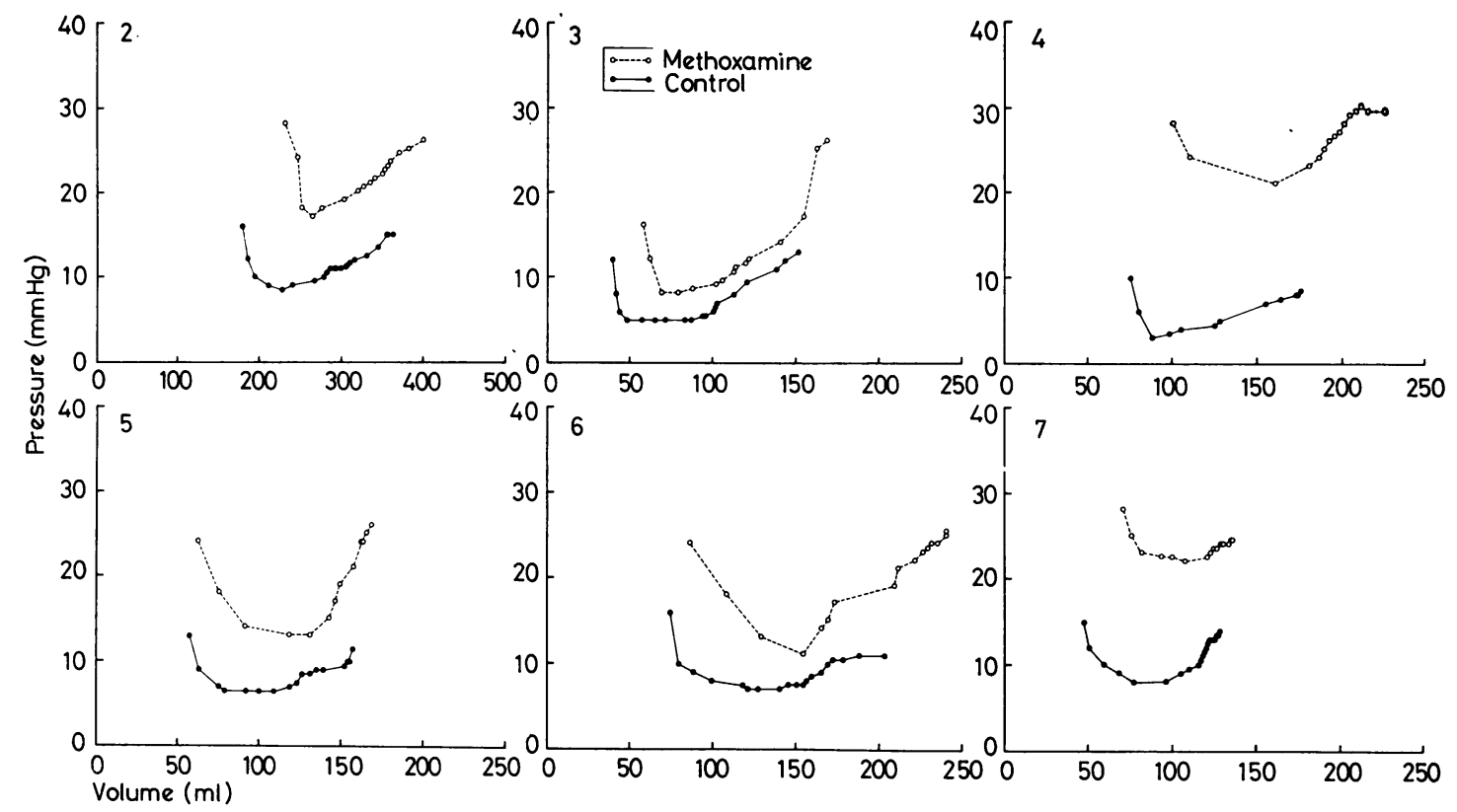

Fig. 3 Left ventricular diastolic pressure-volume curves in 6 patients with chest with syndromes and normal coronary angiography before and during the administration of methoxamine. In each patient there is a substantial upward displacement of pressure-volume curve with methoxamine. Haemodynamic and ventriculographic data for each patient are shown in the Table.

pressure-volume curve, so that, at a given volume, pressures were higher during methoxamine infusion. In the 5 subjects who had serial angiography without methoxamine infusion, there was little change in the pressure-volume relation. Data from 3 of these patients are shown in Fig. 4.

The haemodynamic and angiographic data for the 7 subjects are shown in the Table. Systemic vascular resistance and mean arterial pressure increased significantly with methoxamine. Cardiac index increased slightly while heart rate was controlled and did not change. Mean right artial pressure, left ventricular end-diastolic pressure, left ventricular minimal diastolic pressure, peak $+\mathrm{dP} /$ $\mathrm{dt}$, and peak $-\mathrm{dP} / \mathrm{dt}$ all increased significantly. Left ventricular end-diastolic volume and end-systolic
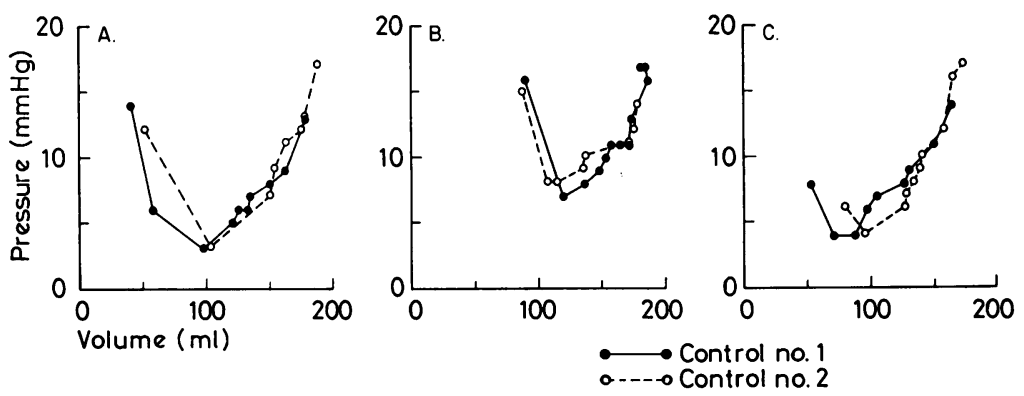

Fig. 4 Left ventricular diastolic pressure-volume curves in 3 of the 5 patients with chest pain syndromes and normal coronary angiography who underwent serial left ventriculography 15 minutes apart but did not receive methoxamine. In each subject there is no apparent difference between the first and second pressure-volume curves, indicating that ventriculography itself was not responsible for the changes in the diastolic pressure-volume curves seen with methoxamine. (Reproduced with the permission of the Journal of Clinical Investigation.) 
volume increased significantly while stroke volume did not change appreciably and ejection fraction fell slightly. I.eft ventricular wall thickness at enddiastole increased slightly but not significantly and left ventricular mass increased significantly. The diastolic filling rate increased during the first third of diastole but changed little during the middle and last third of diastole.

The 5 subjects who had serial angiography without methoxamine infusion had no significant change in left ventricular end-diastolic volume $(142 \pm 14 \mathrm{vs}$ $146 \pm 15 \mathrm{ml})$, wall thickness $(7 \cdot 7 \pm 0.9$ vs $7 \cdot 7 \pm 0.9$ $\mathrm{mm}$ ), or left ventricular mass ( $289 \pm 41$ vs $297 \pm 44 \mathrm{~g}$ ).

\section{Discussion}

Methoxamine hydrochloride is an alpha-adrenergic agonist whose predominant effect in experimental animals and man is vasoconstriction (Eckstein and Abboud, 1962). Previous studies in dogs have shown that methoxamine infusion results in an increase in systemic arterial pressure and systemic vascular resistance, a reflex bradycardia mediated primarily through baroreceptors, a fall in cardiac index, and an increase in pulmonary artery and right atrial pressures (Aviado and Wnuck, 1957; Brewster et al., 1960; Eckstein and Abboud, 1962). The drug has no significant inotropic effect on the human or dog heart (Goldberg et al., 1960; Eckstein and Abboud, 1962), though there is some recent evidence that methoxamine may exert a positive inotropic effect in isolated rabbit and cat papillary muscles at low frequencies of stimulation (Endoh and Schumann, 1975; Rabinowitz et al., 1975). The drug has little effect on venous tone (Eckstein and Hamilton, 1957).

In our study systemic arterial pressure and systemic vascular resistance increased significantly while heart rate was controlled with atrial pacing and did not change. Cardiac index increased slightly, which differs from most previous animal studies, and is probably related to the fact that heart rate was controlled. The slight increase in cardiac index in our subjects may be explained by increases in preload, but an increase in contractility cannot be excluded. Peak positive $\mathrm{dP} / \mathrm{dt}$ increased significantly with methoxamine probably related to increased preload (end-diastolic volume) (Mahler et al., 1975), and peak negative $\mathrm{dP} / \mathrm{dt}$ increased significantly probably because of increased systemic arterial pressure (Weisfeldt et al., 1974b). Both right atrial and left ventricular diastolic pressures increased substantially. In previous animal studies, increased filling pressures with methoxamine have been attributed to increased left ventricular volumes resulting from compensatory left ventricular dilatation in the face of an increased afterload, but left ventricular volumes have not been measured (Brewster et al., 1960). Our study shows that the increased ventricular diastolic pressures are only partly the result of increased left ventricular volumes. The major factor responsible for the increased left ventricular diastolic pressures with methoxamine is an alteration in the left ventricular diastolic pressure-volume relation.

Acute changes in the left ventricular diastolic pressure-volume relation in man have only been recognised recently and the mechanisms responsible for these changes remain unclear. Several investigators have shown an upward shift in the left ventricular diastolic pressure-volume relation (higher pressure at a given volume) in patients with coronary artery disease who develop angina in response to atrial pacing (Barry et al., 1974; Mann et al., 1977) or isometric hand grip (Flessas et al., 1976). This has been attributed to impaired left ventricular relaxation. There is convincing evidence in experimental animals and man that left ventricular relaxation may be impaired with ischaemia (Tyberg et al., 1970; McLaurin et al., 1973; Weisfeldt et al., 1974a), but whether this impaired relaxation extends throughout diastole to alter the pressure-volume relation in middle and late diastole is uncertain. Studies in open chested dogs during acute global ischaemia while on right heart bypass at constant heart rate and aortic pressure and with the pericardium removed, failed to show any change in the pressurevolume relation (Palacios et al., 1976). This raises the possibility that the acute changes in the pressurevolume relation seen in man may be caused by extramyocardial factors rather than intrinsic changes in myocardial properties. Studies with sodium nitroprusside and glyceryl trinitrate administered to patients with congestive heart failure and coronary artery disease have shown a downward shift in the diastolic pressure-volume relation (lower pressure at a given volume) (Parmley et al., 1976; Brodie et al., 1977). One possible reason for this effect is that vasodilators may exert a direct relaxant effect on ventricular muscle (Brodie et al., 1976, 1977), but an alternative explanation is that these drugs may alter external constraints to left ventricular filling. The studies of Alderman and Glantz in which pressures were measured primarily through fluid-filled catheters showed a shift of the pressure-volume curve with both nitroprusside and angiotensin and support of the latter view (Alderman and Glantz, 1976).

In our study, acute systolic loading with methoxamine resulted in an upward shift of the diastolic pressure-volume curve in each subject. While there are several possible explanations for this shift, the 
increase in left ventricular wall mass that also occurred in each subject suggests that acute systolic loading and increases in coronary artery perfusion pressure may result in coronary vascular engorgement and an erectile or stiffening effect on the left ventricular myocardium. This possibility is supported by experimental evidence of animals. In the isovolumic canine left ventricle, Salisbury and his co-authors found that increases in coronary artery perfusion pressure increased the left ventricular enddiastolic pressure; they attributed this to stiffening of the myocardium resulting from an erectile effect caused by the sinusoidal nature of the coronary circulation (Salisbury et al., 1960). Likewise, Ahn et al. (1977) found a direct effect of coronary artery perfusion pressure on diastolic stiffness and thickness in the rabbit left ventricle, and Gaasch and Bernard (1977) found that acute changes in coronary blood flow altered left ventricular wall thickness The importance of these observations is uncertain because Abel and Reis (1970) and Templeton et al. (1972) were unable to show any change in the stiffness of the canine left ventricle with alterations in coronary perfusion pressure and flow. Nevertheless, our data support the observations of Salisbury et al., Ahn $e t$ al., and Gaasch and Bernard and suggest that the human myocardium may act like erectile tissue in response to acute changes in systemic arterial pressure.

The main reservation in drawing this conclusion lies in the limitation in the measurement of left ventricular mass from single plane angiography. The assumption of uniform wall thickness is not precisely true. In addition, it is possible that acute changes in ventricular loading may alter the shape of the left ventricle and invalidate some of the assumptions used in the calculation of left ventricular mass from single plane angiography. These remain potential limitations of this study.

There are several other factors which potentially could be important in influencing the left ventricular diastolic pressure-volume curve. Methoxamine could act directly on the myocardium to impair left ventricular relaxation. In cat papillary muscles, methoxamine causes a slight prolongation of the time for isometric tension to fall to one-half its peak value (RT 1/2) (Rabinowitz et al., 1975), but studies in man have failed to show any direct effect on myocardial function (Goldberg et al., 1960), and it is unlikely that our observations can be explained by a direct effect of methoxamine on left ventricular relaxation. Methoxamine could also potentially impair left ventricular relaxation by inducing myocardial ischaemia due to increased systemic arterial pressure and increased myocardial oxygen demands. The patients selected for our study did not have coronary artery disease or evidence of myocardial ischaemia so this mechanism is unlikely.

Secondly, methoxamine could alter viscous and inertial forces by changing the rate of left ventricular filling and this could affect the diastolic pressurevolume relation. In experimental dog studies, Noble et al. (1969) noted an upward shift of the left ventricular diastolic pressure-dimension curve in early and late diastole with methoxamine, and attributed these changes to altered viscous and inertial forces caused by more rapid ventricular filling in early and late diastole. In our study, the rate of left ventricular filling was increased in early diastole with methoxamine, but changed little in middle and late diastole. Therefore, it appears that altered viscous forces may contribute to the changes in the pressure-volume relation in early diastole in our patients, but they probably cannot account for the changes in middle and late diastole.

There is experimental evidence in dogs that changes in right ventricular loading may alter left ventricular stiffness (Laks et al., 1967; Taylor et al., 1967; Kelly et al., 1971; Bemis et al., 1974). Increases in right ventricular diastolic pressure change the left ventricular diastolic pressure-volume curve such that left ventricular diastolic pressure is higher at a given volume. Presumably this is because of shifts in the interventricular septum so that it limits left ventricular filling (Bemis et al., 1974). In our subjects right ventricular filling pressures increased significantly with methoxamine, and this mechanism could be important in the acute changes in the pressure-volume relation seen in our patients.

Pericardial restriction also could potentially account for the changes in the pressure-volume relation with methoxamine. The pericardium probably offers no restriction to ventricular filling under normal conditions, but it may be capable of exerting a restrictive function when the heart is distended to large volumes (Holt et al., 1960; Holt, 1970). Increases in left ventricular and presumably right ventricular volumes with methoxamine could encroach upon the limited intrapericardial space and cause restriction to left ventricular filling by the relatively non-distensible pericardium (Glantz et al., 1977; Janicki and Weber, 1977; Shirato et al., 1977). We cannot exclude this mechanism, but one might expect partial equalisation of right ventricular and left ventricular filling pressures at end-diastole, which we did not observe.

In summary, an increase in systemic arterial pressure with methoxamine resulted in a substantial upward shift of the left ventricular diastolic pressurevolume curve and an increase in left ventricular mass in each subject. These changes are probably not the result of intrinsic changes in myocardial 
properties, since methoxamine has little or no direct effect on the human myocardium and since the patients studied had no evidence of myocardial ischaemia. The increase in left ventricular mass suggests that acute increases in systemic arterial pressure may increase left ventricular stiffness by coronary vascular engorgement and an 'erectile effect' on the left ventricular myocardium. The study cannot exclude pericardial restriction and changes in right ventricular loading as contributing factors in acute shifts in the left ventricular diastolic pressurevolume curve.

The authors thank the cardiovascular technicians of the C. V. Richardson Cardiac Catheterization Laboratory for their help in obtaining and processing the data.

\section{References}

Abel, R. M., and Reis, R. L. (1970). Effects of coronary blood flow and perfusion pressure on left ventricular contractility in dogs. Circulation Research, 27, 961-971.

Ahn, J. Apstein, C. S., and Hood, W. B., jun (1977). Erectile properties of the left ventricle: direct effect of coronary artery perfusion pressure on diastolic wall stiffness and thickness (abstract). Clinical Research, 25, 201A.

Alderman, E. L., and Glantz, S. A. (1976). Acute hemodynamic interventions shift the diastolic pressure-volume curve in man. Circulation, 54, 662-671.

Aviado, D. M., jun, and Wnuck, A. L. (1957). Mechanisms of cardiac slowing by methoxamine. Fournal of Pharmacology and Experimental Therapeutics, 119, 99-106.

Barry, W. H., Brooker, J. Z., Alderman, E. L., and Harrison, D. C. (1974). Changes in diastolic stiffness and tone of the left ventricle during angina pectoris. Circulation, 49, 255-263.

Bemis, C. E., Serur, J. R., Borkenhagen, D., Sonnenblick, E. H., and Urschel, C. W. (1974). Influence of right ventricular filling pressure on left ventricular pressure and dimension. Circulation Research, 34, 498-504.

Brewster, W. R., jun, Osgood, P. F., Issacs, J. P., and Goldberg, L. I. (1960). Hemodynamic effects of a pressor amine (methoxamine) with predominant vasoconstrictor activity. Circulation Research, 8, 980-988.

Brodie, B. R, Chuck, L., Klausner, S., Grossman, W., and Parmley, W. (1976). Effects of sodium nitroprusside and nitroglycerin on tension prolongation of cat papillary muscle during recovery from hypoxia. Circulation Research, 39, 596-601.

Brodie, B. R., Grossman, W., Mann, T., and McLaurin, L. P. (1977). Effects of sodium nitroprusside on left ventricular diastolic pressure-volume relations. Fournal of Clinical Investigation, 59, 59-68.

Eckstein, J. W., and Abboud, F. M. (1962). Circulatory effects of sympathomimetic amines. American Heart fournal, 63, 119-135.

Eckstein, J. W., and Hamilton, W. K. (1957). Effects of sympathomimetic amines on forearm venous distensibility, pressure and volume (abstract). Circulation, 16, 875.

Endoh, M., and Schumann, H. J. (1975). Frequency dependence of the positive inotropic effect of methoxamine and naphazoline mediated by alpha-adrenoceptors in the isolated rabbit papillary muscle. Naunyn-Schmiedeberg's Archives of Pharmacology, 287, 377-389.
Flessas, A. P., Connelly, G. P., Handa, S., Tilney, C. R., Kloster, C. K., Rimmer, R. H., jun, Keffe, J. F., Klein, M. D., and Ryan, T. J. (1976). Effects of isometric exercise on the end-diastolic pressure, volumes, and function of the left ventricle in man. Circulation, 53, 839-847.

Gaasch, W. H., and Bernard, S. H. (1977). The effect of acute changes in coronary blood flow on left ventricular enddiastolic wall thickness: an echocardiographic study. Circulation, 56, 593-598.

Glantz, S., Misbach, G., Moores, W., and Tyberg, J. (1977). The pericardium substantially affects the dog left ventricular diastole pressure-volume relationship (abstract). Circulation, 55 and 56, Suppl. III, 52.

Goldberg, L. G., Bloodwell, R. D., Braunwald, E., and Morrow, A. G. (1960). The direct effect of norepinephrine, epinephrine and methoxamine on myocardial contractile force in man. Circulation, 22, 1125-1132.

Holt, J. P. (1970). The normal pericardium. American fournal of Cardiology, 26, 455-465.

Holt, J. P., Rhode, E. A., and Kines, H. (1960). Pericardial and ventricular pressure. Circulation Research, 8, 1171-1181.

Janicki, J. S., and Weber, K. T. (1977). Functional significance of the pericardium (abstract). Circulation, $\mathbf{5 5}$ and 56, Suppl. III, 52.

Kasser, I. S., and Kennedy, J. W. (1969). Measurement of the left ventricular volumes in man by single-plane cineangiography. Investigative Radiology, 4, 83-90.

Kelly, O. T., Spotnitz, H. M., Beiser, G. D., Pierce, J. E., and Epstein, S. E. (1971). Effects of chronic right ventricular volume and pressure loading on left ventricular performance. Circulation, 44, 403-412.

Kennedy, J. W., Trenholme, S. E., and Kasser, I. S. (1970) Left ventricular volume and mass from single-plane cineangiocardiogram. A comparison of anteroposterior and right anterior oblique methods. American Heart fournal, 80, 343-352.

Laks, M. M., Garner, D., and Swan, H. J. C. (1967). Volumes and compliances measured simultaneously in the right and left ventricles of the dog. Circulation Research, 20, 565-569.

McLaurin, L. P., Rolett, E. L., and Grossman, W. (1973). Impaired left ventricular relaxation during pacing induced ischemia. Anericam fournal of Cardiology, 32, 751-757.

Mahler, F., Ross, J., jun, O'Rourke, P. A., and Covell, J. W. (1975). Effect of changes in preload, afterload and inotropic state on ejection and isovolumic phase measures of contractility in the conscious dog. American fournal of Cardio$\log y, 35,626-634$.

Mann, T., Brodie, B. R., Grossman, W., and McLaurin, L. P. (1977). Effect of angina on the left ventricular diastolic pressure-volume relationship. Circulation, 55, 761-766.

Noble, M. I. M., Milne, E. N. C., Goerke, R. J., Carlsson, E., Domenech, R. J., Saunders, K. B., and Hoffman, J. I. E. (1969). Left ventricular filling and diastolic pressurevolume relations in the conscious dog. Circulation Research, 24, 269-283.

Palacios, I., Johnson, R. A., Newell, J. B., and Powell, W. J., jun (1976). Left ventricular end-diastolic pressure-volume relationships with experimental acute global ischemia. Circulation, 53, 428-436.

Parmley, W. W., Chuck, L., Chatterjee, K., Swan, H. J. C., Klausner, S. C., Glantz, S. A., and Ratshin, R. A. (1976). Acute changes in the diastolic pressure-volume relationship of the left ventricle. European fournal of Cardiology, 4, Suppl., 105-120.

Rabinowitz, B., Chuck, L., Kligerman, M., and Parmley, W. W. (1975). Positive inotropic effects of methoxamine: evidence for alpha-adrenergic receptors in ventricular myocardium. American fournal of Physiology, 229, 582-585. Rackley, C. E., Dodge, H. T., Coble, Y. D., jun, and Hay, R. E. (1964). A method for determining left ventricular 
mass in man. Circulation, 29, 666-671.

Salisbury, P. F., Cross, C. E., and Rieben, P. A. (1960). Influence of coronary artery pressure upon myocardial elasticity. Circulation Research, 8, 794-800.

Shirato, K., Shabetai, R., Ron, J., jun, Bhargava, V., Franklin, D., McKown, D., and Werner, F. (1977). The effect of the pericardium on diastolic left ventricular pressure-length curves (abstract). Circulation, 55 and 56, Suppl. III, 52-53.

Taylor, R. R., Covell, J. W., Sonnenblick, E. H., and Ross, J., jun (1967). Dependence of ventricular distensibility on filling of the opposite ventricle. American fournal of Physiology, 213, 711-718.

Templeton, G. H., Wildenthal, K., and Mitchell, J. H. (1972). Influence of coronary blood flow on left ventricular contractility and stiffness. American fournal of Physiology, 223, 1216-1220.

Tyberg, J. V., Yeatman, L. A., Parmley, W. W., Urschel,
C. W., and Sonnenblick, E. H. (1970). Effects of hypoxia on the mechanics of cardiac contraction. American fournal of Physiology, 218, 1780-1788.

Weisfeldt, M. L., Armstrong, P., Sculley, H. E., Sanders, C. A., and Daggett, W. M. (1974a). Incomplete relaxation between beats after myocardial hypoxia and ischemia. Fournal of Clinical Investigation, 53, 1626-1636.

Weisfeldt, M. L., Scully, H. E., Fredericksen, J., Rubenstein, J. J., Pohost, G. M., Beierholm, E., Bello, A. G., and Daggett, W. M. (1974b). Hemodynamic determinants of maximum negative $\mathrm{dP} / \mathrm{d} t$ and periods of diastole. American Fournal of Physiology, 227, 613-621.

Requests for reprints to Dr Bruce R. Brodie, 200 East Northwood Street, Greensboro, North Carolina 27401, USA. 